Pamiętnik Literacki 2020, 1, s. 5-17

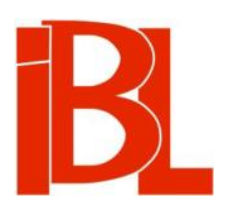

\title{
Miasto polskiego Wieku Światel. Uwagi o krętej ścieżce powrotu
}

\author{
Aleksandra Norkowska
}




\section{1. $\begin{array}{lllllllllllllllllll} & \mathrm{R} & \mathrm{O} & \mathrm{Z} & \mathrm{P} & \mathrm{R} & \mathrm{A} & \mathrm{W} & \mathrm{Y} & \mathrm{I} & \mathrm{A} & \mathrm{R} & \mathrm{T} & \mathrm{Y} & \mathrm{K} & \mathrm{U} & £ & \mathrm{Y}\end{array}$}

Pamiętnik Literacki CXI, 2020, z. 1, PL ISSN 0031-0514

DOI: $10.18318 / \mathrm{pl} .2020 .1 .1$

ALEKSANDRA NORKOWSKA Uniwersytet Kazimierza Wielkiego, Bydgoszcz

\section{MIASTO POLSKIEGO WIEKU ŚWIATEŁ UWAGI O KRETEJ ŚCIEŻCE POWROTU}

Rozprawa Hanny Libury Percepcja przestrzeni miejskiej (1990) stała się zapowiedzią zmian, jakie nastapiły na przełomie XX i XXI wieku w polskich badaniach nad pojmowaniem miasta, sposobami jego postrzegania oraz mówienia o nim. Jej autorka, zainspirowana m.in. koncepcja map mentalnych (mental maps) Kevina Lyncha ${ }^{1}$, opartych na zapisie indywidulanych doświadczeń, uczyniła przedmiotem zainteresowania obszar zurbanizowany. Zdefiniowała go jako „przestrzenną całość nasyconą treściami humanistycznymi" ${ }^{2}$. Kilka lat po ukazaniu się tej publikacji, istotnej nie tylko dla geografii behawioralnej, próbę „poetyckiej "lektury miasta"” 3 podjął Jacek Kaczmarek w pracy Geografia miast. Perspektywa humanistyczna: przykład Nowego Jorku. Wiążąc przestrzeń i miejsce - kluczowe kategorie geografii humanistycznej - z literatura, zwrócił uwage na pejzaż miejski utrwalony w wybranych utworach pisarzy amerykańskich. Celem badacza było jedynie zasygnalizowanie użytecznego dla geografii społecznej potencjału literackich wyobrażeń, które stanowią odzwierciedlenie związku człowieka z przestrzenią urbanistyczną, jego doświadczeń indywidulanych i zbiorowych. Rozwijające się dynamicznie szeroko pojęte studia miejskie oferują obecnie wspólne pole i instrumentarium badawcze dla przedstawicieli różnych dyscyplin. Bliską nauce o literaturze dziedzinę językoznawstwa reprezentuje np. Ewa Sławkowa, która analizując zawarty w poezji Czesława Miłosza językowo-kulturowy obraz miast, m.in. tej jednej z największych metropolii świata, położonej nad rzeką Hudson, sięgnęła po kategorie wypracowane przez onomastykę i lingwistykę kognitywna ${ }^{4}$. Uczona opowiada się za „pluralizmem metodologicznym" ${ }^{\mathrm{N}} \mathrm{w}$ badaniu materiału onomastycznego w utworach literackich,

1 K. Ly n ch, The Image of the City. Cambridge, Mass., 1960. Wyd. polskie: Obraz miasta. Przeł. T. Jeleński. Kraków 2011. Zob. też D. B a chmann-M e di ck, „Cultural Turns”. Nowe kierunki $w$ naukach o kulturze. Przeł. K. Kr z e mi e n i ow a. Warszawa 2012.

2 H. Libura, wstęp w: Percepcja przestrzeni miejskiej. Warszawa 1990, s. 10. Zob. też tej autorki: Percepcja przestrzeni miejskiej - refleksja po latach. W zb.: Percepcja współczesnej przestrzeni miejskiej. Red. M. Ma du row i c z. Warszawa 2007.

3 J. Ka c zma r e k, Geografia miast. Perspektywa humanistyczna: przykład Nowego Jorku. „Acta Universitatis Lodziensis. Folia Geographica Socio-Oeconomica” 1999, nr 2.

4 E. Sławkowa, „Miejsca” (w) historii. Obrazy miasta $w$ poezji Czesława Miłosza (z problemów onomastyki literackiej i lingwistycznej interpretacji tekstu literackiego). W zb.: Miasto. Przestrzeń zróżnicowana językowo, kulturowo i społecznie. Cz. 4. Red. M. Św i ę c i c ka. Bydgoszcz 2012.

5 Ibidem, s. 278. Zob. też m.in. E. Sław k ow a, Od „Parku Joradana” do „parku maszyn”. Z pro- 
a w swoich pracach daje wyraz przekonaniu, że pluralizm jest nie tyle konieczny, co ,jedyny możliwy”. Do zbliżenia przedstawicieli różnych dyscyplin, którzy eksplorują niejednorodne pole badawcze dotyczące przestrzeni urbanistycznej w wieku XVIII przyczyniła się monografia Jerzego Wojtowicza Miasto europejskie w epoce Oświecenia i Rewolucji Francuskiej (1972; 2017). Znajduje się w niej bowiem wielowymiarowy opis mechanizmów dziejowych oraz jednostkowych wydarzeń, omówionych przez autora również w kontekście uwarunkowań społecznych czy kulturowo-instytucjonalnych. Szczególne znaczenie dla historyków literatury oświecenia, którzy zajmują się tematyką miejską, mają dociekania badaczy analizujących wyobrażenia o mieście zawarte głównie w twórczości autorów XX i XXI wieku lub przywołujących je jako kontekst interpretacyjny w rozważaniach dotyczacych innych tekstów kultury6 ${ }^{6}$ Nie sposób tu nie wspomnieć o rozprawie Elżbiety Rybickiej Geopoetyka. Przestrzeń i miejsce we współczesnych teoriach i praktykach literackich (2014), w której zaprezentowano metody i narzędzia umożliwiające badanie powiązań środowiska geograficznego ze światem wyobrażeniowym utrwalonym w literaturze. Monografia podejmująca problematykę z zakresu „Zwrotu przestrzennego”7 zdaje się dzisiaj stanowić wyczerpujące dopełnienie kwestii poruszonej dwie dekady wcześniej przez Kaczmarka, który postulował „analizę geograficzną” utworów literackich. Przyjęcie przez antropolog literatury perspektywy społeczno-kulturowej w opisie miejsca pozwoliło na zbliżenie nauk humanistycznych m.in. do badań nad geografią miast.

Zdaję sobie sprawę, że sposób omówienia tych kilku różnych ujęć fenomenu miasta (ogląd geografa, językoznawcy, antropologa i historyka) jest nazbyt upraszczający. Moim celem było jedynie zwrócenie uwagi, iż dzięki tym wybranym perspektywom postrzegania przestrzeni urbanistycznej, potwierdzającym wielowymiarowość zjawiska, historyk literatury oświecenia ma możliwość stawiania nowych pytań oraz wyjścia poza tradycyjne instrumentarium. Bodźcem wpływającym na powrót do studiów nad tematyką miejską w polskim Wieku Świateł nie może być, oczywiście, atrakcyjność metodologiczna związana z poszerzeniem pola badawczego i wykorzystaniem narzędzi mniej znanych literaturoznawstwu. To nie powab nowego, ale odczucie niedosytu staje u początku drogi. Dałam temu wyraz w dwóch wcześniejszych publikacjach, w których zarysowana została szkicowo problematyka wypływająca z potrzeby odkrywania wyobrażeń o mieście i analizy sposobów ich prezentacji $^{8}$. Kilkuletnie badania skupione na lekturze utworów wybitnych pisarzy

blemów nazewnictwa parków miejskich. W zb.: jw., cz. 6 (Red. M. Ś w i ę c i c ka, M. Pe pliń s ka). Bydgoszcz 2019, s. 242.

6 Zob. m.in. artykuły w tomach: Czytanie miasta-pisanie miasta. Red. A. Zeidle r-J a n is ze wska. Poznań 1997. - Miasto w sztuce - sztuka miasta. Red. E. Rew e r s. Kraków 2010. Zob. też E. Ry bi c ka, Modernizowanie miasta. Zarys problematyki urbanistycznej $w$ nowoczesnej literaturze polskiej. Kraków 2003. - E. Re w e r s, Post-„polis”. Wstęp do filozofii ponowoczesnego miasta. Kraków 2005.

7 E. Ry bi c ka, Krajobraz. Krótkie wprowadzenie. / Landscape: A Brief Introduction. „Herito. Dziedzictwo, Kultura, Współczesność / Heritage, Culture \& the Present” nr 19 (2015): Myślenie krajobrazem. / Thinking the Landscape, s. 20. Zob. też T. Sła w e k, „Pauza w przyzwyczajeniu”. O doświadczeniu krajobrazu. / „A Temporary Cessation of Habit”. On Experiencing the Landscape. Jw.

8 A. Norkowska: Zanim „spojrzymy przez okno”. Uwagi wsteppne o sposobach prezentowania 
epoki i tych, które wyszły spod pióra autorów mniej znanych lub zapomnianych, umożliwiły dokonanie rewizji przedstawionych wówczas poglądów.

Kompendia encyklopedyczno-słownikowe powstałe w okresie oświecenia, a czerpiące obficie $z$ językowego repertuaru staropolszczyzny, zawierają rozmaite ujęcia leksemu „miasto”. Utrwalony w nich obraz jest rezultatem krzyżowania się różnego typu spostrzeżeń. W Zbiorze potrzebniejszych wiadomości, porzadkiem alfabetu ułożonych Ignacego Krasickiego ${ }^{9}$, w Niektórych wyrazach porzadkiem abecadła zebranych i stosownymi do rzeczy uwagami objaśnionych Franciszka Salezego Jezierskiego ${ }^{10}$ - „słowniku quasi-komunałów” ${ }^{11}$, oraz w Słowniku języka polskiego Samuela Bogumiła Lindego (1807-1814) ${ }^{12}$ zakres semantyczny leksemu wyznaczaja trzy kategorie: społeczno-kulturowa, administracyjna i przestrzenna ${ }^{13}$. Odpowiadają im następujące obszary tematyczne, które wskazano w definicjach leksemu „miasto” lub w objaśnieniach wyrazów odsyłających do pojęć związanych z szeroko rozumianym życiem w mieście: społeczność miejska, miasto główne / stolica, spójny układ przestrzenny i architektoniczny.

Pierwsze $z$ tych pól semantycznych zyskało obszerne omówienie. Obraz miasta odsłaniający jego ustrojowo-organizacyjny wymiar ukształtowany został dzięki przywołaniu porządku prawnego antycznych urbes (głównie Rzymu), procesu formowania się zbiorowości miejskiej w Rzeczypospolitej (XIII-XVIII w.) oraz oświeceniowej koncepcji państwa i społeczeństwa. Słownik Lindego zawiera zestawienia opozycyjne, nie uwzględnione w dawniejszych kompendiach z czasów stanisławowskich. W publikacjach Krasickiego i Jezierskiego nie przeciwstawiono bowiem miastu wprost, gdy weźmie się pod uwagę kryterium przestrzenne, następujących sfer: 1) stancji i domu, 2) przedmieścia, 3) wsi. W pierwszym polskim nowocześnie skonstruowanym zbiorze leksykalnym miasto to: 1) sfera publiczna wyraźnie oddzielona od sfery prywatnej, 2) centrum, $z$ którym skontrastowano peryferia, 3) forma osadnicza, którą odróżniają od wsi planowe zagospodarowanie przestrzeni, organ władzy wykonawczej i profil zatrudnienia mieszkańców ${ }^{14}$.

Do ścieżek wchodzących w zakres tego niejednorodnego pola badawczego należą studia nad wskazaną w słowniku wydanym na początku XIX wieku antytezą:

miasta $w$ piśmiennictwie oświecenia. W zb.: Europejski wiek osiemnasty: uniwersalizm myśli, różnorodność dróg. Studia i materiały. Red. M. Dębowski, A. Grześ kowiak-Krwawicz, M. Zw i e r zy k o w s ki. Kraków 2013; Scalanie obrazów, czyli o potrzebie i sposobach odkrywania miasta $w$ piśmiennictwie polskiego Wieku Świateł. „Prace Polonistyczne” seria 68 (2013): Z warsztatu badaczy oświecenia. Aktualia.

9 I. Kr a s i c k i, Zbiór potrzebniejszych wiadomości, porzadkiem alfabetu ułożonych. T. 1-2. Warszawa-Lwów 1781, t. 1: s. 175, 195-200, 208, 310, 311, 482; t. 2: s. 90, 459, 565.

10 F. S. J e zi e r s ki, Niektóre wyrazy porzadkiem abecadła zebrane i stosownymi do rzeczy uwagami objaśnione. Warszawa 1791, s. 72, 84, 116, 129, 138, 150, 154, 156-157, 160, 166, 218, 248, $254,256$.

11 T. Ko s t k i e w i c z o w a, Publicystyka Franciszka Salezego Jezierskiego z lat 1788-1791. Z zagadnień literackiej perswazji. W: Oświecenie. Próg naszej wspótczesności. Warszawa 1994, s. 229.

12 S. B. Lin d e, Słownik języka polskiego. T. 2, cz. 1: M-O. Warszawa 1809, s. 10, 67-68, 89-90.

13 Na wieloznaczność tego wyrazu, odsyłającego do jednego z podstawowych pojęć funkcjonujących w języku polskim, zwrócił uwagę m.in. J. Wi e c z o r e k: Analiza znaczeniowa leksemu "miasto” we wspótczesnej polszczyźnie. „Rozprawy Komisji Językowej” t. 38 (2011).

Zob. Lin d e, Słownik języka polskiego, t. 6: U-Z (1814), s. 224, hasło: Wieś. 
miasto-wieś. Stanowiła ona nie tylko wyraz zakorzenionej w kulturze opozycji, która $z$ wyjątkowa siłą organizowała negatywne wyobrażenie o polskim mieście Wieku Świateł. Tego, iż narzędziem antyurbanistycznego gestu była głównie literatura, dowodzi przywołany w objaśnieniu leksemu „miasto” materiał egzemplifikacyjny. Krótko mówiąc: cytaty pochodzące $z$ traktatów antycznych i renesansowych, w których zwrócono uwagę na to, iż miasto to rzecz wspólna, publiczna, pospolita - wsparły pierwsze $z$ wymienionych ujęć (łączące miasto $z$ łacińskim leksemem „civitas”: 'społeczność obywateli'). A ogląd miejskiego bytowania z perspektywy wsi osadzony jest jedynie na odwołaniach do wybranych tytułów dzieł komediowych, które wchodzą w skład liczącej kilkadziesiąt tomów XVIII-wiecznej serii „Teatr Polski, czyli Zbiór Komedii, Dram i Tragedii” (wyd. 1: 1779). Ustalenia Zygmunta Leśnodorskiego, Jerzego Michalskiego, Stefana Tomaszewskiego i Teresy Kostkiewiczowej ${ }^{15}$, które są rezultatem wielostronnych analiz, jednoznacznie dowiodły, iż wizję miasta w literaturze zdominowało negatywne wyobrażenie miejskiego życia. Co istotne, włączenie oświeceniowych wypowiedzi o mieście w obszar analizowanych zjawisk historyczno- i socjologicznoliterackich, które - jak wskazuje podtytuł książki wybitnej znawczyni epoki - stanowiły „próg naszej współczesności”, nabiera w perspektywie 25 lat szczególnego znaczenia. Wybrzmiewa ono również w monografii Rybickiej Modernizowanie miasta. Zarys problematyki urbanistycznej $w$ nowoczesnej literaturze polskiej, w której sposób omówienia głównego tematu dowodzi „istotnego pokrewieństwa pytań, jakie do tej pory w rodzimych badaniach nad modernizmem stawiane były niezależnie od siebie" ${ }^{16}$. Wstępne rozważania zawierają bowiem stwierdzenie, iż w literaturze polskiego oświecenia „mamy do czynienia z sytuacją w pewnym stopniu paradoksalną - z miastem "omówionym", lecz nie "przedstawionym", pozbawionym zresztą reprezentacji i w szerszym znaczeniu"17. Mit antyurbanistyczny - jak zauważyła autorka, posiłkując się również wcześniejszymi ustaleniami - „zajął w oświeceniu miejsce miasta” ${ }^{18}$.

Ponowna lektura tekstów źródłowych, wsparta literaturą przedmiotu dotycząca przyczyn i przejawów omawianego fenomenu, skłania do wniosku, że ta kategoryzująca wizja „złego miasta” zdominowała nie tylko imaginację autorów czasów stanisławowskich. Zawładnęła ona bowiem późniejszym procesem badawczym, analizą i myśleniem o wariantach miejskiego motywu oraz sposobach wykorzystania i realizacji schematów wyobrażeniowych utrwalonych w literaturze całej epoki. O ich wyrazistości decydowała siła archetypicznego obrazu o antyczno-biblijnej tradycji, którą wsparły poglądy Jeana-Jacques’a Rousseau, postrzegającego miasto jako symbol cywilizacji. Krytyka bytowania w przestrzeni urbanistycznej, wzmocniona na gruncie polskim negacją Warszawy, ujawniała się ze szczególną siła

Z. Le śn o d o r s ki, Miasto i mieszczanie w powieści stanisławowskiej. „Pamiętnik Literacki” 1935, z. 1/2. - J. Mich als ki, Warszawa, czyli o antystołecznych nastrojach $w$ czasach Stanisława Augusta. W zb.: Warszawa XVIII wieku. Z. 1. Warszawa 1972. - S. To mas zew ski, Motywy miejskie $w$ romansie stanisławowskim. „Prace Polonistyczne” seria 41 (1985). - T. Ko s t ki e wic z ow a, Wizje miasta $w$ literaturze wieku oświecenia. W: Oświecenie.

16 W. Tomasik, rec.: E. Ry bicka, Modernizowanie miasta. Zarys problematyki urbanistycznej $w$ nowoczesnej literaturze polskiej. Kraków 2003. „Pamiętnik Literacki” 2006, z. 1, s. 253.

17 Rybicka, Modernizowanie miasta, s. 45. 
m.in. w poezji konfederacji barskiej. Odzwierciedlono w niej nieprzychylne nastawienie narodu szlacheckiego do polityki prowadzonej przez Stanisława Augusta Poniatowskiego ${ }^{19}$. Król rezydował wszak w mieście, które stanowiło ośrodek reform Rzeczypospolitej. Można dziś sądzić, że skrupulatny i uważny opis rozbieżności między odmiennymi kategoriami (rodzimość/swojskość - obcość/inność) ${ }^{20}$, który oddaje w sposób czytelny dychotomia przestrzenna (miasto-wieś; vide hasło Miasto w słowniku Lindego), pozbawił badaczy ostrości widzenia. Niewykluczone, że również i w tym tkwi przyczyna niewielkiego zainteresowania historyków literatury udziałem w obradach sekcji Miasto, przestrzenie $i$ ich reprezentacje $w$ świetle nowych idei, które przebiegały w ramach III Kongresu Badaczy Osiemnastego Wieku: Wiek XVIII jako zmiana - Rzeczpospolita i Oświecenie (Poznań 2016). Winą za tak wyraźnie odczuwalne osłabienie wrażliwości na sygnały płynące $z$ wypowiedzi o mieście obarczyć należy stan „poznawczego uwięzienia” ${ }^{21}$. Termin ten, przyjęty za Ryszardem Nyczem, przybliżającym cele współczesnej humanistyki, jednoznacznie określa sytuację, w jakiej znalazł się badacz miasta Wieku Świateł w Polsce. Korzystajac $z$ respektem $z$ prac znawców piśmiennictwa staropolskiego i oświeceniowego, dąży on do wskazania i rozróżnienia sposobów opisu wieloaspektowego doświadczenia życia w przestrzeni urbanistycznej, ale szuka nieco po omacku. Modyfikacja spojrzenia, a więc i określenie nowych zadań jest niezbędne w działaniu mającym na celu kontynuowanie poszukiwań. Powinny one się łączyć z wykroczeniem poza zjawiska już „omówione” w tekstach i „przedstawione” na drodze uważnego poznania.

Wśród prac badawczych dotyczących tematyki miasta w piśmiennictwie oświecenia wyróżnić należy, obok już wymienionych, w których zwrócono uwagę na funkcje obrazów i sposoby przedstawienia miejskiej codzienność (co jest powiązane w większym lub mniejszym stopniu $z$ dyskursem antymiejskim) ${ }^{22}$, dwa wyraziste nurty. Pierwszy z nich koncentruje się na żywo dyskutowanej w czasach stanisławowskich kwestii mieszczańskiej, poruszanej najczęściej w wypowiedziach publicystycznych i w utworach dramatycznych, rzadziej w poezji ${ }^{23}$. Drugi natomiast

Zob. A. N o r k o w s k a, „Czartowski potomek”. O wizerunku Stanisława Augusta w poezji barskiej. W: Wizerunki władcy. Stanisław August Poniatowski w poezji okolicznościowej (1764-1795). Kraków-Warszawa 2006.

Zob. m.in. T. Ko s tk i e w i c zow a, Problemy uniwersalizmu i rodzimości. W: Polski Wiek Świateł. Obszary swoistości. Wrocław 2002.

21 R. Ny c z, Kultura jako czasownik. Sondowanie nowej humanistyki. Warszawa 2017, s. 115.

22 Zob. też m.in. R. Kaleta, M. Klimowi c z, Prekursorzy oświecenia. Wrocław 1953. - I. Kad uls ka, Obraz Warszawy w komediach szkolnych Franciszka Bohomolca. „Prace Historycznoliterackie” t. 16 (1993): Oświecenie. Studia i szkice. - M. Li s i c k a, Życie Warszawy oczami Stanisława Kostki Potockiego. W zb.: Światy oświeconych i romantycznych. Doświadczenia, uczucia, wyobraźnia. Red. B. Mazurkowa. Katowice 2015.

23 Zob. m.in. J. Łu k a s z e w i c z, Drama mieszczańska w twórczości Franciszka Zabłockiego. „Prace Polonistyczne” seria 60 (2005). - A. N o r k o w s k a: Kniaźnin wobec przeobrażeń stanu mieszczańskiego: „Na śmierć J[ana] Dekierta, prezyd[enta] Warszawy”. W zb.: Czytanie Kniaźnina. Red. B. Mazurkowa, T. Chachulski. Warszawa 2010; „Z płaczem czytałem...” Problematyka mieszczańska $w$, „iście do redakcji” „Monitora”. W zb.: Epistolografia $w$ dawnej Rzeczypospolitej. Red. P. B or ek, M. Olma. T. 2: Stulecia XVIII-XIX. Kraków 2011; Znawca sztuki o (nie)szczęściu mieszczan. (Stanisław Kostka Potocki, „Dobre czasy. Bajka”). W zb.: O spuściźnie literackiej Stani- 
dotyczy konstrukcji descriptio urbis oraz stosunkowo nielicznej grupy utworów zawierających retoryczną pochwałę miast. Badacze podróżopisarstwa i tekstów dokumentarnych przedmiotem uwagi uczynili ekfrazy ośrodków urbanistycznych z uwzględnieniem obowiązującego od antyku modus scribendi ${ }^{24}$. Prozatorskie relacje, oprócz drobiazgowych często informacji dotyczacych topografii odwiedzanych miejsc i spotkanych w nich ludzi, odzwierciedlają również emocje, których źródłem była rozciągająca się przed podróżnikami panorama miasta lub bezpośredni kontakt z obiektami architektonicznymi.

Wśród historyków literatury wzrasta zainteresowanie techniką wyrażania doznań jednostkowych w oświeceniowych wspomnieniach $\mathrm{z}$ podróży i w opisach przestrzeni urbanistycznej. Łączyć należy tę sytuację z zachodzącymi w Wieku Świateł zmianami w sposobie ujawniania subiektywności w tekście literackim ${ }^{25}$. „Pierwiastek osobisty” wyłaniający się z wybranych dzienników epoki przybliżyła Magdalena Partyka. Poddała ona analizie m.in. zapis wrażeń Stanisława Staszica dokonany podczas jego wojażowania po miastach Europy w latach $1789-1805^{26}$. Alina Aleksandrowicz pierwsze wydanie Niektórych zdarzeń, myśli i uczuć doznanych za granica Marii Wirtemberskiej (1978) poprzedziła uwagami na temat przeobrażeń w konstrukcji bohatera-narratora, których przejawem jest osobiste doświadczenie,

stawa Kostki Potockiego. Studia i szkice. Red. D. Folga-J anu szew ska, T. Chachulski. Warszawa 2018.

24 Zob. A. Cieński, Pamiętnikarstwo polskie XVIII wieku. Wrocław 1981. - P. Ka czyń ski, Niemieckie i włoskie miasta w oczach oświeconego Polaka. „Prace Historycznoliterackie” t. 16 (1993). M. B ob e r-J a n k ow ska, „Miasto duże, piękne i porzadne, [...] koronacja cesarzów sławne”. Retoryczny kształt deskrypcji miast $w$ oświeceniowych dziennikach podróży. W zb.: Tradycja retoryczna $w$ kulturze oświecenia i romantyzmu. Red. A. Se we ry n, M. J. G o n d e k. Lublin 2016. M. N a le p a, Hugona Kołtataja i Juliana Niemcewicza relacje z podróży przez miasta i miasteczka wołyńskie. W: Porozbiorowe migracje $w$ literaturze późnego oświecenia. Studia nad wybranymi tekstami. Rzeszów 2018. Zob. też rozprawy zamieszczone w zb.: Polski „Grand Tour” $w$ XVIII i poczatkach XIX wieku. Red. A. Ro ćk o. Warszawa 2014.

25 Zob. H. Dzi e c h cińs ka: Miasto widziane oczyma polskich peregrynantów. W: O staropolskich dziennikach podróży. Warszawa 1991; Czas, przestrzeń, miasto. W: Pamiętniki czasów saskich. Od sentymentalizmu do sensualizmu. Bydgoszcz 1999. Badania nad podmiotowością w piśmiennictwie epoki podjęła T. Ko st ki e w i c z ow a (Poezja i czułe serce. Szkic o sensach „czucia” w świadomości poetyckiej oświecenia i Mickiewicza. W zb.: Studia romantyczne. Red. M. Żmigrodzka. Wrocław 1973; W kręgu serca i czucia. W: Horyzonty wyobraźni. Ojęzyku poezji czasów oświecenia. Warszawa 1984, s. 168-172). Zob. też najnowsza prace P. B a k ow s k i ej: Konstrukcje podmiotu lirycznego $w$ poezji Stanisława Kostki Potockiego (uwagi wstępne). W zb.: O spuściźnie literackiej Stanisława Kostki Potockiego.

26 Badaczka przywołała m.in. opis odzwierciedlający zachwyt, jaki zrodził się w spacerowiczu podczas kontaktu z architektonicznym dziełem sztuki: „Stanałem w zdziwieniu! [...] Na koniec tak wspaniałego placu ukazuje się wspaniały pałac. Jeszcze pierwszym zdumieniem umysł zachwycony, a już zmysły umysł obraca na tę świątynię" (Dziennik podróży Stanisława Staszica. Wyd. Cz. Leśni e w s ki. Warszawa 1931, s. 114. Cyt. za: M. Party k a, Pierwiastek osobisty w oświeceniowych dziennikach z podróży. W zb.: Polski „Grand Tour” w XVIII i poczatkach XIX wieku, s. 124). Por. m.in. zapis wrażeń doznanych przez podróżnika wjeżdżającego do Edynburga: „Tyle przedmiotów razem skupionych i razem przedstawiających się umysłowi muszą zachwycać najozięblejszego widza. Teraźniejszy król angielski, gdy zwiedzał Szkocję roku 1822, wjeżdżając tędy do stolicy i rzuciwszy wzrok na tę okolicę i miasto, wykrzyknął w zachwyceniu: „Got, what a sight! [...]” (K. La c h S zy r m a, Anglia i Szkocja. Przypomnienie z podróży roku 1820-1824 odbytej. Przypisy, posł. P. Hertz. Warszawa 1981, s. 51). 
wpływające na kształt utrwalonego w utworze wizerunku miasta ${ }^{27}$. Przywołane tu prace dotyczące percepcyjnego zaangażowania podmiotu, mimo iż dają odpowiedź na rzadko formułowane pytania, w niewielkim jeszcze stopniu (!) wzbogacają wiedzę na temat nowych sposobów budowania wywodów, w których zawarto zapis odczuć i emocji doznawanych w przestrzeni miejskiej. Ważnym zadaniem stojącym przed badaczem jest analiza i porównanie technik zaprezentowania sfery publicznej przez pryzmat usytuowania w niej: 1) postaci doświadczających „bycia w mieście” - spacerowicza poruszającego się pieszo, saniami lub konno 28 (J. Ancuta, Spacer nocny po Warszawie; J. Czyż, Doniesienie przyjacielowi), pasażera pojazdu (M. Wirtemberska, Malwina, czyli domyślność serca; S. Rzewuski, Ite volate metra et teneras imitata columbas) i obserwatora ruchu ulicznego z przestrzeni prywatnej (Myśli patrzacego przez okno na ulice $w$ Warszawie 1791); bądź 2) osób przyglądających się miastu $\mathrm{z}$ oddali: ze zbliżającego się do niego lub oddalającego się pojazdu (F. Karpiński, Podróż do Krakowa i jego okolic. List do J[aśnie] O[świeconej] księżny Barbary z Duninów Sanguszkowej, marszałkowej w[ielkiej] W[ielkiego] Ks[ięstwa] Lit[ewskiego), z gondoli (M. Wirtemberska, Niektóre zdarzenia, myśli i uczucia doznane za granica [...) lub z kosza przyczepionego do powietrznej bani ${ }^{29}$ (F. D. Kniaźnin, Balon, czyli wieczory puławskie. Poema $w$ dziesięciu pieśniach).

$Z$ zarysowanego dotychczas stanu badań nad wyobrażeniem miasta Wieku Świateł wynika, iż zachodzi potrzeba zwiększenia aktywności badawczej, zmierzającej chociażby do zauważenia i omówienia zjawisk nie dostrzeżonych jeszcze „okazjonalnie” przez historyków literatury, którzy stawiaja pytania o sposoby wyrażania innych sfer ludzkiego doświadczenia. Rezultatem takich działań są ustalenia Marcina Cieńskiego, które w sposób istotny wsparły studia „miejskie”. Omawiając stosunek polskich pisarzy doby oświecenia do nowych tendencji w technice przedstawiania pejzażu ${ }^{30} \mathrm{w}$ literaturze europejskiej, badacz wskazał również na jego miejską reprezentację w Malwinie Marii Wirtemberskiej ${ }^{31}$. Analiza wyobrażeń natury dzikiej i ujarzmionej przez człowieka (ogrody i parki) umożliwiła „wkroczenie" do miasta poprzez posłużenie się jedną z najczęściej w geografii humanistycznej wykorzystywanych kategorii analitycznych. To właśnie „myślenie krajo-

Zob. m.in. A. Aleks a nd row i cz, Polska „podróż sentymentalna”. W: M. Wirte m be r s ka, Niektóre zdarzenia, myśli i uczucia doznane za granica. Z rękopisów oprac., wstęp A. Al e k s a ndrowicz. Warszawa 1978.

Zob. artykuły zamieszczone w tomie Walking the Streets of Eighteenth-Century London: John Gay's Trivia (1716) (Ed. C. Brant, S. E. Why ma n. Oxford 2007).

Zob. E. Ra n o c hi, Widok $\mathrm{z}$ lotu balonem. O przemianie paradygmatu percepcji $i$ narracji na przełomie XVIII i XIX wieku (Jean Paul, Potocki). W zb.: Eklektyzmy, synkretyzmy, uniwersa. Z estetyki dzieła epoki oświecenia i romantyzmu. Red. A. Zi ołowicz, R. Dąbrowski. Kraków 2014.

30 Terminu „krajobraz” używam tu zamiennie ze słowem „pejzaż”, które odnosi się najczęściej do przedstawienia mniej rozległego obszaru w dziełach sztuki. Problematykę nazewnictwa zasygnalizował F. Plit w pracy Pięć nurtów badań krajobrazowych $w$ Polsce - czy jest $w$ nich miejsce dla krajobrazów rekreacyjnych? (Problemy Ekologii Krajobrazu” t. $27\langle 2010\rangle$ : Krajobrazy rekreacyjnekształtowanie, wykorzystanie, transformacja, s. 331).

31 M. C i eń s ki, Domyślne serce i wrażliwa na pejzaż dusza: „Malwina” Marii Wirtemberskiej. W: Pejzaże oświeconych. Sposoby przedstawiania krajobrazu w literaturze polskiej w latach 1770-1830. Wrocław 2000, s. 198-201. 
brazem" ${ }^{32}$ doprowadziło do połączenia dwóch biegunowo odmiennych przestrzeni ${ }^{33}$. Widok mostu prowadzącego na Pragę i zabudowań prawobrzeżnej Warszawy inkrustowany jest bowiem elementami przyrody (zakolem rzeki, tarczą słoneczną przekraczająca horyzont, drzewem owocowym i zwierzętami). Natura i kultura postrzegane jako „kontrobrazy” ${ }^{44}$ zostały ze sobą harmonijnie powiązane:

Pod rozłożystą gruszką, nad samą wodą, siedział człowiek sędziwy, ciemnej twarzy, który na długiej żerdzi podrywką ryby łowił. Przy nim kobieta młoda, z płcią takoż śniadawą i czarnymi oczami, zawieszone na drzwiach siecie naprawiała. U nóg ich kadź stała $z$ wodą pełną rybek, w której mała dziewczynka, także $z$ włosami i oczami czarnymi, grzebała, drażniąc się z kotem, co na rybki czatował. Długi zakręt Wisły widać było $z$ tego miejsca, łódka wartem płynęła, most i Praga horyzont kończyły i zachodzące słońce, właśnie w porę oświetlając ten obraz, czyniło go godnym pędzla Werneta ${ }^{35}$.

Poszukiwanie malowniczych ujęć w literaturze epoki doprowadziło do ponownej lektury zacytowanego fragmentu i dowartościowania literackiej wizji miasta okresu oświecenia. Ten wycinek czasoprzestrzeni, wykrojony $\mathrm{z}$ obrazu stolicy Księstwa Warszawskiego, utrzymany jest w estetyce the picturesque, na której podłożu kształtowała się w XVIII wieku teoria krajobrazu ${ }^{36}$. Zastosowany przez pisarkę mechanizm prowadzący do sprofilowania wizualnego obrazu miasta został dostrzeżony przez Cieńskiego, który za pomocą nowego narzędzia odkrył zawarte w nim sensy. Scena nad brzegiem Wisły ukazująca powiązanie człowieka ze środowiskiem przyrodniczym stała się źródłem wzruszenia tytułowej bohaterki. A wskazane przez narratorkę powinowactwo tego „żywego obrazu”37 ze światem przedstawionym przez Claude’a Josepha Verneta (1714-1789), pejzażysty i czołowego reprezentanta nurtu preromantycznego, zdaje się nie tylko utrwalać doznanie zmysłowe, ale i odsyłać do sfery doświadczenia estetycznego, którego podmiotem jest Malwina ${ }^{38}$. Ustalenia stanowiące rezultat poszukiwań skupiających się na wizji natury wpłynęły, co może się wydać paradoksalne, na zmianę aksjologiczną obrazu miasta. W działaniach podjętych przez historyka literatury posługującego się kategorią krajobrazu (estetycznego) dostrzec należy ważny kierunek prowadzący ku odsłanianiu szczególnych wymiarów przestrzeni urbanistycznej. Wiążą się one m.in. $z$ mechanizmami odzwierciedlenia wrażeń, których źródłem są bodźce zmysłowe ${ }^{39}$. Oprócz przywołanego tu fragmentu współtworzącego pejzaż wizualny

Ry b i c ka, Krajobraz. Krótkie wprowadzenie. / Landscape: A Brief Introduction. - Sła w e k, op. cit.

Zob. Ny c z, op. cit., s. 87. Autor, zwracając uwagę na „hybrydyczną naturę” krajobrazu, odnotował jego rolę „w przełamywaniu ograniczeń badawczych wynikających z myślenia w kategorii binarnych opozycji”.

Pojęcie kontrobrazu przywołuję tu za H. Beltingiem (Antropologia obrazu. Szkice do nauki o obrazie. Przeł. M. B ryl. Kraków 2007, s. 83).

[M. W i r t e m b e r s k a], Malwina, czyli domyślność serca. T. 1. Warszawa 1816, s. 182-183.

Zob. B. Fy d ry c z a k, Krajobraz. Od estetyki "the picturesque" do doświadczenia topograficznego. Poznań 2013.

Zob. M. Ko mza, Żywe obrazy. Między scena, obrazem a ksiażka, Wrocław 1995. Za zwrócenie mi uwagi na tę publikację dziękuję pani prof. Magdalenie Górskiej.

Zob. więcej na ten temat: A. N o r k o w s ka, O mieście jako przestrzeni doznań estetycznych $w$ literaturze polskiego oświecenia. W zb.: Eklektyzmy, synkretyzmy, uniwersa.

Problematyka sensualna związana z życiem w mieście oświecenia stanowiła przedmiot moich badań, których rezultatem są studia i szkice. Zob. m.in.: Dźwięki $w$ przestrzeni sakralnej $w$ literackim 
znajdujemy w tekstach epoki bogatą w różnorodne dźwięki miejską audiosferę. Rzadziej odzwierciedlano sygnały zapachowe. Mniej liczne utwory zawierają zapis odczuć smakowych i taktylnych. Szczegółowe badania nad wizją miasta wykreowaną za pomocą odwołań do jakości sensualnych pozwolą na poszerzenie wiedzy na temat sposobów opisywania bodźców, doznań i doświadczeń odzwierciedlających indywidualne zaangażowanie czy też wykorzystanie przez twórców schematów zakorzenionych w zbiorowej pamięci. Badania nad zastosowanymi przez autorów technikami oddającymi doświadczenie ruchu i percepcji otoczenia przybliżają do rekonstrukcji zapisanych w literaturze wyobrażeń, które wskazują na wieloaspektowość odczuć związanych z miejskim życiem.

O ile „myślenie krajobrazem” umożliwiło odsłonięcie miejskiego pejzażu, o tyle „myślenie przestrzenią" wiedzie badacza w odwrotnym kierunku - ku opozycyjne$\mathrm{mu}$ wobec miasta obszarowi. Jest nim środowisko przyrodnicze, które podlega przekształceniom w wyniku działań ludzkich. Przyjęcie za punkt wyjścia tematu natury zawładniętej przez człowieka pozwala odkrywać nie ujawniony jeszcze potencjał tkwiący w oświeceniowych wyobrażeniach o mieście. Inspiracją do obrania takiej perspektywy, którą chciałabym wesprzeć przykładem, stał się namysł przedstawicieli różnych dyscyplin humanistycznych nad obrazem natury w kulturze wczesnonowożytnej ${ }^{40}$. Powrót do uniwersalnej problematyki relacji natura-kultura nie jest w tej sytuacji równoznaczny z powrotem do oglądu antymiejskiego. Skierowanie spojrzenia na proces obejmowania przyrody w posiadanie przez człowieka umożliwia pewną modyfikację tego spojrzenia i jeżeli nie złagodzenie konfliktu, to choćby odsunięcie narracji o „złym” mieście, snutej z pozycji polskiego Sarmaty, który w wiejskiej oazie broni wiary, wolności i narodowej tradycji. Mam tu na uwadze wprowadzenie w obszar miejskich zainteresowań - jeszcze bardziej wyraziście człowieka, który, dzięki swemu umysłowi i podejmowanym działaniom (praxis), jest w stanie zawładnąć częścią świata materialnego (przyrodą ożywioną i nieożywioną). To najpopularniejszy bohater utworów o mieście czasów stanisławowskich - osobnik pozbawiony kontaktu $z$ przyrodą, co negatywnie wpływa na jego physis i sferę dyspozycji psychicznych ${ }^{41}$. Miasto postrzegane jako ucieleśnienie idei wspólnoty prowokuje do pytań o swoich twórców i (świadomych) użytkowników, a nie o fircyka czy damę modną. Homo urbanus, wyłaniający się $z$ wypowiedzi poruszających temat genezy miasta i powstania ośrodków miejskich, usytuowany jest pomiędzy kulturą a naturą. Twórca miasta to istota rozumna, która dzięki swym umiejętnościom zagospodarowuje potencjał materialny tkwiący w najbliższym otoczeniu.

obrazie XVIII-wiecznego miasta. W zb.: Miasto. Przestrzeń zróżnicowana językowo, kulturowo i społecznie, cz. 4; Codzienne zapachy miasta utrwalone w piśmiennictwie polskiego oświecenia. W zb.: Codzienność i niecodzienność oświeconych. Red. B. Ma z u rkow a, z udziałem M. Ma r c in kowski j i S. P. Dąbrow ski ego. [T.] 2: W rezydencji, w podróży i na scenie publicznej. Katowice 2013.

40 Badacze biorący udział w projekcie zainicjowanym przez A. Nowicką-Jeżową przedstawili wyniki swych poszukiwań podczas ogólnopolskiej konferencji naukowej Obraz natury $w$ kulturze intelektualnej, literackiej i artystycznej doby staropolskiej i oświecenia (Warszawa, 18-20 IX 2019).

41 Taki wizerunek mieszkańca miasta został przedstawiony m.in. w poemacie M. J ás kiewicza Szczęśliwość życia wiejskiego (1773?) oraz w Projekcie nieuskutecznionym. Proza i wierszem W. I. Marewicza (1788). 
Współczesny fiński architekt Juhani Pallasmaa uczynił dłoń, która „myśli”, tytułową bohaterką książki o architektonicznym środowisku człowieka ${ }^{42}$. Wśród autorów wypowiedzi nieświadomie nawet wskazujących na znaczenie ręki w przeobrażaniu świata materialnego i jego wykorzystywaniu są Adam Naruszewicz (Do Najjaśniejszego Pana $w$ czasie jego przejazdu przez Końskie kuźniczymi fabrykami sławne, domu Małachowskich dziedziczne, Warszawa 1787) i Wincenty Kamieński (Przypadki lubelskie. Poema oryginalne wierszem takim jak „Monachomachium” ułożone $w$ dziewięciu pieniach, [b. m.] 1810).

Powiązanie konkretnej społeczności $\mathrm{z}$ danym terenem nie zostało ukazane w literaturze oświecenia jako jednorazowy akt. Miasto bowiem, ulegając ciagłym przeobrażeniom, $z$ uwagi na wzrost liczby ludności, poszerza zajmowana przez siebie powierzchnię. Najbardziej plastyczne wyobrażenie tego procesu zawarte zostało w wierszu Jakuba Jasińskiego zatytułowanym Na wzrost Warszawy:

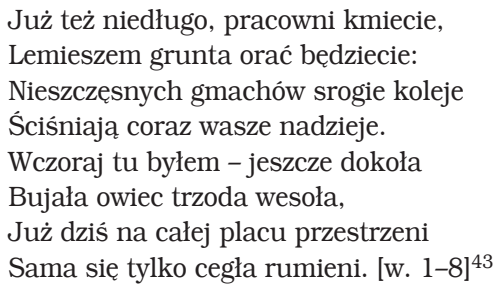

Szybkie i chaotyczne działanie, które zmierza do przekształcania sposobu użytkowania ziemi - z rolniczego na zurbanizowany - niesie ze soba, w opinii pisarza, powracajacego w latach osiemdziesiatych XVIII wieku z Wilna do stolicy, negatywny skutek, jakim jest zabudowa, szkodliwa nie tyle dla krajobrazu, co dla środowiska. Ból, jaki rodzi obraz zniszczenia, połączony został z poczuciem utraty, rzadko odzwierciedlanym w piśmiennictwie dotyczącym miasta. Metamorfozę terenów rolniczych przedmieść przedstawiono w perspektywie nie tylko dosłownej, ale i symbolicznej. Utwór ten odsyła do poglądów Rousseau, ale i, jak zauważył Jacek Wójcicki, do Horacjańskiej myśli przeciwko miastu i zbytkom (tak m.in. w odzie II 15 Iam pauca arato iugera regiae) ${ }^{44}$. Symbolem przeobrażeń zachodzących w polskiej metropolii czasów panowania Stanisława Augusta jest cegła, „rumieniąca się” na placu budowy, który zajmuje miejsce pól uprawnych i pastwisk. Ten wypalany w ogniu materiał ceramiczny, wykonany z mieszanki gliny, przywodzi na myśl

J. Palla smaa, Myślaca dłoń. Egzystencjalna i ucieleśniona madrość $w$ architekturze. Przeł. M. Choptiany. Kraków 2015.

J. Ja siń ski, Na wzrost Warszawy. Cyt. z: „Świat poprawiać - zuchwałe rzemiosto”. Antologia poezji polskiego oświecenia. Oprac. T. Kostkiewiczowa, Z. Goliński. Warszawa 1981, s. 326.

J. W ó j c i c k i, Z Horacym w balonie nad stanisławowska Warszawa. Intertekstualna perspektywa wiersza Jakuba Jasińskiego. W zb.: Długie trwanie. Różne oblicza klasycyzmu. Red. R. D ą b rows ki, B. D o p a r t. Kraków 2011. Z. Z a c h m a c z (Jakub Jasiński-generat i poeta. Nad biografia i tekstami. Warszawa 1995, s. 102-103) przypuszcza, że wiersz ten jest wyrazem negatywnych refleksji, jakie zrodziły się w Jasińskim w wyniku obserwacji zmian dokonujących się w Warszawie w latach osiemdziesiątych XVIII wieku. Poeta odwiedzał wówczas stolicę, przybywając do niej z Wilna. 
budulec, z którego wzniesiono miasto i wieżę $(\operatorname{Rdz} 11,1-7)$. Poetycką wizję rozszerzającej się w swych granicach Warszawy dopełniono prezentacją wznoszacych się ku niebu „sztucznych” (w. 24) balonów i łodzi, które pokonują bezdenne morza. Te wytwory ludzkich rąk, dowodzące zdolności umysłu, stanowią znak potęgi osiągniętej dzięki połączeniu wysiłków wielu osób. Wsparł je w wierszu obraz Boga niecierpliwie oczekującego na powrót człowieka, którego dążenia doprowadziły do nieszczęść i „wzrostu nienawiści” (w. 39) ${ }^{45}$. Obudowanie obrazu „niebotycznych [...] gmachów" (w. 11) ${ }^{46}$ przedstawieniem innych wytworów kultury oraz wizją międzyludzkich relacji prowadzacych do wojen przywodzi na myśl biblijną budowlę stanowiąca symbol ludzkiej pychy.

W tym utworze, „niespójnym” i „niejasnym”, co - jak zauważa Wójcicki - „wynika [...] z nie przemyślanej gruntownie metody wykorzystania matrycy antycznej do opisu rzeczywistości nowożytnej" 47 , uchwycono doświadczenie podmiotu, który dzieli się swoimi refleksjami na temat zmian zachodzących na skonkretyzowanych w wierszu przestrzeni i czasie („wczoraj”/„dziś”). To, że w trakcie analizy wiersza badacz miasta odwołuje się do kategorii miejsca, umożliwia wskazanie ważnego aspektu codzienności mieszkańców Warszawy. Obraz utrwalony przez Jasińskiego jest jednym $z$ argumentów dowodzących, iż przestrzeń urbanistyczna Rzeczypospolitej, zrujnowana działaniami wojennymi, jakie toczyły się w XVII i XVIII stuleciu, „nabierała rumieńców” po 20-letnich przeszło rządach Stanisława Augusta.

O ile poetycki obraz materiału murarskiego, jakim jest czerwona cegła, odczytać należy jako symbol rozbudowy stolicy w czasach stanisławowskich, o tyle w literaturze porozbiorowej znakiem naprawy i modernizacji polskich miast jest zapowiedź przywrócenia, po 200 przeszło latach, stałej przeprawy przez Wisłę, która połaczyłaby prawobrzeżną i lewobrzeżna część stolicy Królestwa Kongresowego. Podmiot liryczny poematu Rzeki polskie Kajetana Jaksy Marcinkowskiego (1821), opublikowanego blisko 30 lat po powstaniu utworu Na wzrost Warszawy Jasińskiego, z dumą anonsuje wzniesienie tej nowoczesnej w owym okresie budowli:

\footnotetext{
Ten gród ma drugie miasto na przeciwnym brzegu:

Ileż mostów zerwała Wisła w bystrym biegu!

Były drewniane, Polska może mieć stalowy,

Już twórca Sofijówki plan gotuje nowy ${ }^{48}$.
}

Autor w jednym z wielu komentarzy, którymi opatrzył swój poemat, wyjaśnił odbiorcy, iż konstruktorem stałej przeprawy ${ }^{49}$, oczekiwanej od 200 przeszło lat przez mieszkańców, jest Ludwik Metzel, „znakomity wielką znajomością różnych umiejętności” ${ }^{50}$. Uwaga odnosi się do żywo dyskutowanej (przez specjalistów tech-

J a s ińs ki, loc. cit.

Ibidem.

Wój cicki, op. cit., s. 47.

K. Jaxa Marcinkowski, Rzeki polskie, poema pomniki sławy narodowej opiewajace. Warszawa 1826, s. 23.

Pierwszy (drewniany) most, postawiony z rozporządzenia Zygmunta Augusta w 1573 roku, którego pochwałe zawarł Jan Kochanowski we fraszce Na most warszawski (Fraszki, Księgi wtóre), nie wytrzymał naporu kry w 1603 roku.

Jaxa Marcinkowski, op. cit., s. 23, przypis 13. 
niki mostowej i mieszkańców stolicy zainteresowanych poprawą komunikacji) pionierskiej na gruncie polskim konstrukcji, która wyróżniało wśród tego typu budowli inżynierskich powstałych za granica „zastosowanie części przejazdowej opartej na łańcuchach zamiast najczęściej stosowanego na zachodzie podwieszenia"51. Mimo że projekt budowy mostu rzecznego autorstwa twórcy słynnego ogrodu Stanisława Szczęsnego Potockiego w Zofiówce (1802) zyskał pozytywne opinie, to zaniechano tego nowatorskiego wówczas przedsięwzięcia ze względów ekonomicznych.

Ostatnia kwestia, na jaką chcę zwrócić uwagę, wysuwając propozycje nowych czy mniej znanych ścieżek badawczych, które zainspirują i, jak można przypuszczać, ułatwią dostrzeżenie nie odkrytych jeszcze komponentów obrazu miasta, związana jest z memory studies - popularnymi wśród reprezentujących różne dyscypliny humanistyczne badaczy zajmujących się współczesnymi tekstami kultury. Powstałe w schyłkowym okresie oświecenia Rzeki polskie, których przytoczony fragment zawierał pochwałe polskiej myśli technologicznej, zbudowane zostały z wyobrażeń utrwalających doświadczenie miejsc. Współtworzą one przestrzeń dziejową narodu pozbawionego państwa. $\mathrm{W}$ poemacie uwydatniono to silne i trwałe powiązanie dwóch wymiarów miasta: fizycznego i społecznego. Widok elementów architektoniczno-urbanistycznych, które podmiot utworu - porwany „wartkim [...] biegiem”" ${ }^{2}$ rzeki mija na swej drodze, wyzwala opowieść o wzniosłych i tragicznych losach Rzeczypospolitej, o znamienitych postaciach i wydarzeniach historycznych. Śpiewak-wędrowiec, głosząc piękno ziemi ojczystej, szczególną uwage poświęca „pomnikom sławy narodowej" usytuowanym nad brzegami Wisły, Warty, Bugu, Niemna i Sanu. Dzięki wykorzystanej w utworze strategii pisarskiej to głównie Kraków i Warszawa stanowia wizualne dominanty odsyłające do zbiorowej przeszłości. Perspektywa miejsca pamięci (lieux de mémoire) ${ }^{53}$ i mnemotoposu (pojmowanego jako miejsce ulokowania wspomnien, które staje się fundamentem pamięci wspólnotowej ${ }^{54}$ ) od niedawna wykorzystywana jest również w badaniach nad piśmiennictwem oświecenia. Teresa Kostkiewiczowa posłużyła się m.in. tym instrumentarium badawczym, analizując literackie „reprezentacje” pamięci indywidulanej i zbiorowej oraz wizję czasoprzestrzeni utrwaloną w epice i dramacie drugiej połowy XVIII wieku ${ }^{55}$. Monika Stankiewicz-Kopeć przybliżyła procesy modernizacyjne zachodzace w polskich miastach w późniejszym okresie, w pierwszych dekadach XIX stulecia, czyniąc

W. S t e r n e r, Niezrealizowany projekt mostu tańcuchowego przez Wiste pod Warszawa, „Kwartalnik Historii Nauki i Techniki” 1957, nr 2, cz. 2, s. 290. Tam też m.in. raport Deputacji Towarzystwa Przyjaciół Nauk (1820), która wydała pozytywną opinię na temat budowy mostu. Należy dodać, że do pomysłu Metzla już nie powrócono, a Warszawa doczekała się kolejnej stałej przeprawy przez Wisłę, projektu Stanisława Kierbedzia, dopiero w 1864 roku. Jaxa Marcinkowski, op. cit., s. 12.

53 Zob. A. Szpocińs ki, Miejsca pamięci („lieux de mémoire”). „Teksty Drugie” 2008, nr 4. Polski badacz odnosi się (s. 12) do prekursorskich ustaleń P. N ory (Mémoire collective. W zb.: Faire de l'histoire. Sous la dir. de J. Le Goff, P. Nora. Paris 1974) dotyczacych „zinstytucjonalizowanych form zbiorowych wspomnień przeszłości". wieku. Toruń 2019. 
przedmiotem zainteresowania m.in., istotny ze względu na przedmiot tych rozważań, mechanizm kształtowania się miasta historycznego i nowoczesnego ${ }^{56}$.

Przedstawiony w tym szkicu wstępny przegląd mało znanych źródeł, bardziej opisowy niż interpretacyjny, ale już wzmocniony ustaleniami innych dyscyplin humanistyki ${ }^{57}$ - pozwala na odsłonięcie wizerunku miasta oświecenia jako rezultatu aktywności człowieka, który posługując się „myślącą dłonią, wznosi gmachy $\mathrm{Z}$ „rumieniącej się” cegły. Wizja stalowej przeprawy nad rzeka zdaje się symbolicznie łączyć przedindustrialna przestrzeń urbanistyczną z miastem epoki przemysłu i technologii ${ }^{58}$.

Pora stwierdzić, że nie sposób rozpatrywać obecnie wyobrażeń o życiu w mieście jedynie w tradycyjnej perspektywie. Takie spojrzenie nie zaspokaja współczesnych potrzeb poznawczych, czego dowodza przywołane przeze mnie nieliczne jeszcze prace badaczy epoki. Myślenie przestrzenią ${ }^{59}$, krajobrazem, miejscem, doświadczaniem, postrzeganiem, zmysłami, stanowiące tu główny przedmiot uwagi, to nie jedyny kierunek poszukiwań. Szczególnej troski wymaga kwestia mieszczańska, zagadnienie kultury literackiej i praktyk pisarskich, sposób zaprezentowania ośrodków prowincjonalnych, wobec tak silnej dominacji obrazów Warszawy, czy omówienie opozycji miasto-natura. Oświetlenie m.in. tych kwestii przynieść powinno odpowiedź na najważniejsze pytanie: co zmieniło się w czasach oświecenia w myśleniu o mieście i mówieniu o nim?

\section{Abstract \\ ALEKSANDRA NORKOWSKA Kazimierz Wielki University, Bydgoszcz ORCID: 0000-0002-8072-3975}

\section{THE CITY OF THE POLISH AGE OF ENLIGHTENMENT REMARKS ON A WINDING WAY OF RETURN}

Among the tasks the literary historian undertakes is a multi-faceted analysis of the image of the city contained in the Polish Enlightenment writing. Raising it as a subject of interest which is different from the scrutinised variant of the motive based on the anti-urbanistic rhetoric, and connected with urban life criticism, is possible, inter alia, due to applicability of the newest findings of research in the fields of humanistic geography and memory studies. The article suggests an expansion of the research field and employing less known literary studies tools to pinpoint and describe the various components of the conceptual model of the city profiled by the writers of the epoch.

M. St a n k i e w i c z - K o p e ć, Literackie forpoczty nowej świadomości urbanistycznej i cywilizacyjnej. $\mathrm{W}$ : Miasto i cywilizacja $w$ kontekście sporów modernizacyjnych $w$ piśmiennictwie polskim lat 1800-1830. Studia. Kraków 2018, s. 161-188. tylko do wybranych prac znawców tematu, reprezentujących różne dziedziny nauki. 